\title{
Early Expression of Sodium Channel Transcripts and Sodium Current by Cajal-Retzius Cells in the Preplate of the Embryonic Mouse Neocortex
}

\author{
Mireille Albrieux, ${ }^{1,2}$ Jean-Claude Platel, ${ }^{2}$ Alain Dupuis, ${ }^{2}$ Michel Villaz, ${ }^{2}$ and William J. Moody ${ }^{1}$ \\ ${ }^{1}$ Department of Biology, University of Washington, Seattle, Washington 98195, and ${ }^{2}$ Canaux Ioniques et Signalisation, Institut National de la Santé et de la \\ Recherche Médicale E9931, Département Réponses et Dynamique Cellulaires, 38054 Grenoble, France
}

\begin{abstract}
In mouse, the first neurons are generated at embryonic day (E) 12 and form the preplate (PP), which contains a mix of future marginal zone cells, including Cajal-Retzius cells, and subplate cells. To detect developmental changes in channel populations in these earliestgenerated neurons of the cerebral cortex, we studied the electrophysiological properties of proliferative cells of the ventricular zone and postmitotic neurons of the PP at E12 and E13, using whole-cell patch-clamp recordings. We found an inward sodium current in $55 \%$ of PP cells. To determine whether sodium currents occur in a specific cell type, we stained recorded cells with an antibody for calretinin, a calcium-binding protein found specifically in Cajal-Retzius cells. All calretinin-positive cells had sodium currents, although so did some calretinin-negative cells. To correlate the Na current expression to Na channel gene expression with the Cajal-Retzius cell phenotype, we performed single-cell reverse transcription-PCR on patch-clamp recorded cells to detect expression of the Cajal-Retzius cell marker reelin and the Na channel isoforms SCN 1,2, and 3. These results showed that virtually all Cajal-Retzius cells (97\%), as judged by reelin expression, express the $\mathrm{SCN}$ transcript identified as the SCN3 isoform. Of these, $41 \%$ presented a functional Na current. There is, however, a substantial SCN-positive population in the $\mathrm{PP}(27 \%$ of SCN-positive cells) that does not express reelin. These results raise the possibility that populations of pioneer neurons of the PP, including Cajal-Retzius cells, gain neuronal physiological properties early in development via expression of the $\mathrm{Na}_{\mathrm{v}} 1.3$ (SCN3) Na channel isoform.
\end{abstract}

Key words: Na current; Cajal-Retzius; reelin; preplate; single-cell RT-PCR; patch clamp

\section{Introduction}

Neurons in the cerebral cortex are generated in a proliferative region known as the ventricular zone (VZ), which lines the lateral ventricle of each telencephalic hemisphere (McConnell, 1995). Neurogenesis in the dorsomedial mouse neocortex occurs between embryonic days (E) 11 and E17, during which the cells undergo 11 cell divisions (Takahashi et al., 1995). A fraction of the progeny of each division exits the cell cycle and begins neuronal differentiation, migrating out of the $\mathrm{VZ}$, across the intermediate zone, and into the cortical plate (CP) (Takahashi et al., 1996). In addition to this radial migration, there is also a tangential migration of cells arising in the ganglionic eminence to take up positions in the developing cerebral wall (De Carlos et al., 1996; Meyer et al., 1998). The first phase of neurogenesis occurs between E11 and E13 and gives rise to a group of neurons that form the preplate (PP) (Marin-Padilla, 1998), which is later split

Received Dec. 12, 2002; revised Dec. 4, 2003; accepted Dec. 8, 2003.

This work was supported by National Institutes of Health Grant NS38116, by a grant from the Région RhôneAlpes, and by an Institut National de la Santé et de la Recherche Médicale fellowship. We thank B. Lambolez and B. Cauli for helpful advice on single-cell reverse transcription-PCR. We also thank F. Couraud, J. L. Eubanks, H. L. Picken-Bahrey, and Dr. D. A. Currie for stimulating scientific discussions.

Correspondence should be addressed to Dr. W. J. Moody, Department of Zoology, University of Washington, Box 351800, Seattle, WA 98195. E-mail : profbill@u.washington.edu.

DOI:10.1523/JNEUROSCI.3548-02.2004

Copyright $\odot 2004$ Society for Neuroscience $\quad$ 0270-6474/04/241719-07\$15.00/0 into the marginal zone (MZ) and the subplate (SP) (Luskin and Shatz, 1985; Valverde et al., 1995). The PP neurons include CajalRetzius cells, other MZ cells, and SP neurons. These earlygenerated neurons perform an essential role in the development of the cerebral cortex (Chun and Shatz, 1989b; Frotscher et al., 2001). Cajal-Retzius cells regulate the phenotype of the radial glial cells (Soriano et al., 1997) and may direct neuronal migration (Frotscher, 1998; Marin-Padilla, 1998). SP cells play an essential role in the initial formation of efferent cortical connections that will pioneer later axonal pathways of $\mathrm{CP}$ neurons (Shatz and Luskin, 1986; Kim et al., 1991; McConnell et al., 1994). The majority of these early PP neurons disappear postnatally (Chun et al., 1987; Chun and Shatz, 1989a).

Few electrophysiological studies have been performed on Cajal-Retzius cells. Embryonically, these cells display a K current with an inactivating component (Mienville and Barker, 1997). Postnatally, they are capable of repetitive action potential activity, and this plus their low resting potential and NMDA receptormediated calcium influx and synaptic activity may contribute to their excitotoxic cell death after birth (Zhou and Hablitz, 1996; Mienville and Pesold, 1999; Radnikow et al., 2002).

In the present experiments, we sought to monitor the earliest phases of electrophysiological differentiation of the Cajal-Retzius cells. Because these neurons serve important functions at very early stages of cortical development, we reasoned that they might 
also show precocious physiological differentiation. We show that as E12 VZ cells become postmitotic and invade the PP, distinct patterns of functional $\mathrm{Na}^{+}$channel expression emerge. By combining immunohistochemical staining and single-cell reverse transcription (RT)-PCR coupled with patch-clamp recordings, we showed that at the PP stage (E12-E13) virtually all CajalRetzius cells (97\%; identified by expression of reelin) expressed $\mathrm{Na}$ channel transcripts of the SCN3 isoform and that almost half $(41 \%)$ of these already displayed inward $\mathrm{Na}$ currents. An additional reelin-negative PP population also expressed Na channel transcripts and functional Na currents. These results indicate the very early physiological differentiation of at least two populations of PP neurons.

\section{Materials and Methods}

Tissue preparation. Timed-mated C57/Bl6 mice (B\&K Universal, Kent, WA; or Iffa Credo, Lyon, France) were killed in a $\mathrm{CO}_{2}$ chamber on gestational day E12 or E13. Pups were removed from the uterus, and the brains were dissected out in ice-cold artificial cerebral spinal fluid (ACSF), which contained (in $\mathrm{mM}$ ) : $119 \mathrm{NaCl}, 2.5 \mathrm{KCl}, 1.3 \mathrm{MgCl}_{2}, 2.5$ $\mathrm{CaCl}_{2}, 1 \mathrm{NaH}_{2} \mathrm{PO}_{4}, 26.2 \mathrm{NaHCO}_{3}, 11$ D-glucose, bubbled with $95 \%$ $\mathrm{O}_{2} / 5 \% \mathrm{CO}_{2}$ to yield a $\mathrm{pH}$ of 7.4 . Brains were embedded in $3 \%$ low temperature gelling agarose (Sigma, St. Louis, MO) at $30-32^{\circ} \mathrm{C}$ and placed on ice. After the agarose solidified, $200 \mu \mathrm{m}$ thick coronal slices of the forebrain were cut in cold ACSF with a Vibratome 1000 (Technical Products International, St Louis, MO) and allowed to recover in room temperature ACSF for 60-90 min.

Electrophysiological recordings. Recordings were performed in the dorsomedial and dorsolateral neocortex with the whole-cell or perforated patch configuration of the patch-clamp technique. Slices were placed in a constantly perfused chamber (ACSF bubbled with $95 \% \mathrm{O}_{2} / 5 \% \mathrm{CO}_{2}$ ) at room temperature $\left(20-22^{\circ} \mathrm{C}\right)$. Visualization was performed with an $\mathrm{Ax}$ ioskop upright microscope (Carl Zeiss, Oberkochen, Germany) equipped with a Zeiss water immersion $63 \times$ objective and differential interference contrast optics. Cell type was determined by location in the slice, with zones ( $\mathrm{PP}$ vs VZ) marked in slices from the same stage embryo stained with TuJ1 (Fig. 1A). Cells were targeted for recording within approximately the first three to four cell layers from the pia, a region that comprises most of the PP. This region contains mainly cells with bipolar morphology (Fig. 1A). Pipettes (12-14 M 2 ) were pulled using a PP-83 puller (Narashige, Tokyo, Japan), coated with Sylgard 184 (Dow Corning, Midland, $\mathrm{MI}$ ), and filled with $\mathrm{K}$ or Cs gluconate internal solution, which contained (in $\mathrm{mm}$ ) : $100 \mathrm{KGlu}$ or CsGlu, 0.5 EGTA, $5 \mathrm{MgCl}_{2}, 40$ HEPES, 2 Na-ATP, and 0.3 Na-GTP, pH 7.25. Recordings were done using an Axopatch-1D amplifier (Axon Instruments, Foster City, CA) and P-Clamp software (Axon Instruments). Electrode capacitance was compensated after establishment of a tight seal. Series resistance compensation was not used given the low resistance of our electrodes and the relatively small currents involved. Leak subtraction was not used because mean current amplitudes are $\sim 100-400 \mathrm{pA}$ and mean input resistance is $\sim 3800 \mathrm{M} \Omega$. All potentials were corrected for a measured junction potential of $9 \mathrm{mV}$, pipette negative. Capacitance of the cells are evaluated from steps of current induced under triangle-wave voltage command, as described previously (Moody and Bosma, 1985). Statistical tests were performed using Student's $t$ test if not otherwise noted, and all results are presented as mean $\pm \mathrm{SD}$.

Cell filling and immunostaining. In some experiments, patch pipettes were back-filled with 2\% Texas Red Dextran 3000 MW, lysine fixable (Molecular Probes, Eugene, OR). During the recording, cell filling was observed using a Texas Red filter set (excitation, $560 \mathrm{~nm}$; emission, 645 nm; Chroma Technology Inc., Brattleboro, VT). Then, the pipette was removed, and the slice was fixed for $1 \mathrm{hr}$ in fresh $4 \%$ paraformaldehyde in PBS (in mM): $3.16 \mathrm{NaH}_{2} \mathrm{PO}_{4}, 6.84 \mathrm{Na}_{2} \mathrm{HPO}_{4}$, and $0.15 \mathrm{NaCl}, \mathrm{pH} 7.2$. Fixation and all subsequent steps were performed at room temperature and were light protected. After washing with TBS plus $0.2 \%$ Triton X-100 (in mм: 0.1 Tris base and $0.15 \mathrm{NaCl}, \mathrm{pH} 7.5$ ), slices were blocked with $3 \%$ BSA (Jackson ImmunoResearch Laboratories, West Grove, PA), 3\%
A
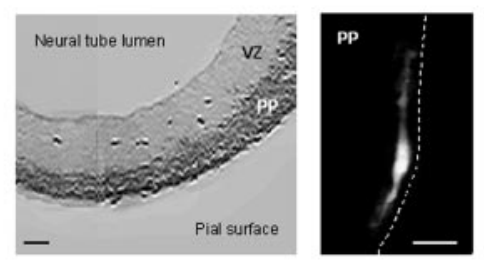

B

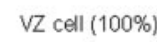

C

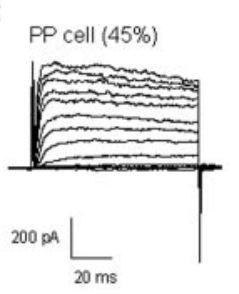

D

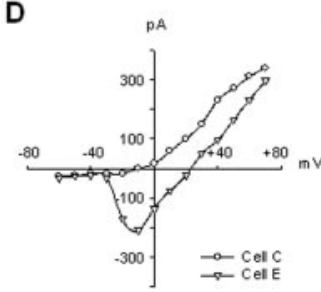

E

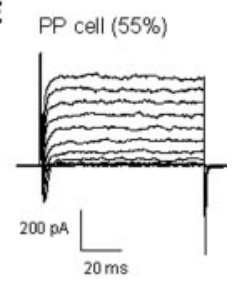

Figure 1. Appearance of a sodium current in addition to the potassium current as neurons invade the PP. A, Neocortical part of an embryonic coronal slice (dorsal part to the bottom) with the neuronal population, corresponding to the PP, stained with the neuronal-specific TuJ1 antibody (dark gray) and the unlabeled proliferative population corresponding to the VZ (light gray). Right, Texas Red dye fill of a typical PP cell. The dashed line indicates the position of the pia. Scale bars, $50 \mu \mathrm{m}$. B, Representative outward K currents in a VZ cell. In this and all records, depolarizing voltage stages, 80 msec in duration, were applied from a holding potential of -61 $\mathrm{mV}$ to voltages between -71 and $+61 \mathrm{mV}$ in $10 \mathrm{mV}$ increments. $C$, Representative outward $\mathrm{K}$ currents obtained in $45 \%$ of PP cells. D, Current-voltage plots from traces recorded in the two PP cells showed in $C(O)$ and $E(\triangle)$, measured 2.3 msec after onset of the depolarizing pulse. $E$, Representative outward K currents and inward Na currents obtained in 55\% of PP cells.

NGS (Jackson ImmunoResearch Laboratories), and 0.2\% Triton X-100 in TBS (dilution/blocking buffer) for $30 \mathrm{~min}$. Slices were then incubated overnight with the neuron-specific anti-class III $\beta$ tubulin antibody (TuJ1; dilution, 1:500 in dilution/blocking buffer; Babco, Richmond, CA) or the Cajal-Retzius cell-specific anti-calretinin antibody $\left(\mathrm{Ca}^{2+}\right.$ bound and unbound conformation; dilution, 1:750 in dilution/blocking buffer; Chemicon, Temecula, CA). After washing in TBS plus $0.2 \%$ Triton X-100, slices were incubated for $2 \mathrm{hr}$ with the appropriate FITCconjugated secondary antibody [goat anti-mouse IgG (Jackson ImmunoResearch Laboratories) for TuJ1 immunostaining or goat anti-rabbit IgG (Chemicon) for anti-calretinin immunostaining] diluted (1:300) in dilution/blocking buffer. After washing in TBS plus $0.2 \%$ Triton X-100, slices were mounted in Vectashield (Vector Laboratories, Burlingame, CA). For nuclear staining, slices were incubated for $3 \mathrm{~min}$ in $300 \mathrm{~nm}$ $4^{\prime}$,6-diamidino-2-phenylindone (DAPI) in TBS plus $0.2 \%$ Triton X-100 during one of the washes. Images were acquired with a DEI-750D digital camera (Optronics, Goleta, CA) coupled with an Axioskop microscope (Carl Zeiss), using an oil immersion $40[\times$ objective. Images were stored and analyzed using Adobe Photoshop 4.0.

Single-cell RT-PCR. Single-cell RT-PCR was performed mainly as described by (Lambolez et al., 1992). Before the experiments, $9.5 \mu \mathrm{l}$ of a reverse transcriptase mix composed of $1 \times$ RT buffer, $0.5 \mathrm{~mm}$ of each dNTP, $5 \mu \mathrm{m}$ random primers, $10 \mathrm{~mm}$ DTT, and $20 \mathrm{U}$ of RNAsin was distributed in $0.2 \mathrm{ml}$ thin wall microtubes (Stratagene, La Jolla, CA) kept at $4^{\circ} \mathrm{C}$. After whole-cell recording, most of each cell was aspirated into the patch pipette. The pipette was removed from the slice, and the tip of the pipette was broken in a prepared RT-PCR tube that was immediately frozen in dry ice. At least one control consisting of an unpatched filled pipette was made every seven patched cells. At the end of a patch-clamp experiment, all the frozen tubes were thawed. Superscript II (100 U) was added to the tubes, followed by an overlay of $20 \mu \mathrm{l}$ of mineral oil. These tubes were then left overnight at $37^{\circ} \mathrm{C}$ (Lambolez et al., 1992).

The next day, $40 \mu \mathrm{l}$ of a PCR mix was added through the oil of each reverse transcriptase tube to give the following final concentrations: $1 \times$ Titanium PCR buffer, $0.2 \mathrm{~mm}$ dNTPS, $25 \mathrm{~nm}$ of each primer (five pairs of primers), and $2.5 \mathrm{U} / 50 \mu \mathrm{l}$ of Titanium polymerase (Clontech, Palo Alto, CA). A 1 min step at $95^{\circ} \mathrm{C}$ allowed the inactivation of reverse transcrip- 
Table 1. Primer pairs designed for RT-PCR

\begin{tabular}{|c|c|c|c|}
\hline Primers & Sequence $\left(5^{\prime} \rightarrow 3^{\prime}\right)$ & $\begin{array}{l}\text { Annealing } \\
\text { temperature }\end{array}$ & RT-PCR product size \\
\hline Actin F1 & ATATCGCTGCGCTGGTCGTC & $55^{\circ} \mathrm{C}$ & $753 \mathrm{bp}$ \\
\hline Actin R1 & ACCGCTCGTTGCCAATAGTGAT & & \\
\hline Calretinin F3 & TTGGCGGAAGTATGACACAGAC & $51^{\circ} \mathrm{C}$ & 302 bp \\
\hline Calretinin R3 & САATATAGCCGCTTCCATCCTT & & \\
\hline Reelin F2 & ACTCTGGCAACCGTACAATAATG & $55^{\circ} \mathrm{C}$ & $343 \mathrm{bp}$ \\
\hline Reelin R2 & GACCGGATCAGCAGAAGAACTA & & \\
\hline SCNFUA & TTCATCGGCGTCATCAT & $51^{\circ} \mathrm{C}$ & $565 \mathrm{bp}$ \\
\hline SCNRUA & ACATCATCAGAGCAAAGAGC & & \\
\hline SCNFUB & GGAGACATTCCTCCAGAGAT & $51^{\circ} \mathrm{C}$ & 556 bp (SCN1/ \\
\hline SCNRUB & ATCATGACGTCAGACAGCTT & & $\begin{array}{l}\text { SCN2) or } 560 \mathrm{bp} \\
\text { (SCN3) }\end{array}$ \\
\hline
\end{tabular}

SCNFUB, SCNRUB, SCNFUA, and SCNRUA are universal SCN primers designed in short regions of strict identity between CDNA MSCN1a, MSCN2a, and MSCN3a. F, Forward equal direct sense primer; R, reverse.

tase, the denaturation of newly synthesized RNA/DNA duplex, and the "hotstart" activation of Titanium polymerase. The samples were then submitted to 30 cycles of amplifications $\left(30 \mathrm{sec}\right.$ at $95^{\circ} \mathrm{C}, 30 \mathrm{sec}$ at $56^{\circ} \mathrm{C}, 1$ min at $68^{\circ} \mathrm{C}$ ), followed by a single extension step of $5 \mathrm{~min}$ at $68^{\circ} \mathrm{C}$ (Robocycler 96; Stratagene). Aliquots ( $2 \mu \mathrm{l})$ of these first-step multiplex PCRs were then used as templates for a second run of PCRs. This second run was performed essentially as the first one with two differences : (1) one pair of primers (100 nM of each primer) was added per PCR, and (2) each PCR was run at the experimentally determined optimal annealing temperature of the primer pair used. After this second PCR, $10 \mu \mathrm{l}$ of each sample was run on a $2 \%$ agarose gel. Gels were stained with SYBR Green I (Molecular Probes) for half an hour and scanned on Fluorimager SI (VistraFluorescence). The five couples of primers used in this study are presented in Table 1. They were designed with the software Primer Select (DNAstar) using cDNA sequence for mice reelin (GenBank accession number U24703), calretinin (GenBank accession number 6970318), and $\beta$-actin (GenBank accession number 6671508). In the case of the $\mathrm{Na}$ channel isoforms, the three SCN1, SCN2, and SCN3 $\alpha$-subunit isoforms were chosen because they are known to be expressed in embryonic mouse cortex (Beckh et al., 1989). Only small parts of the corresponding SCN cDNA and genes could be found in GenBank. Therefore, the putative cDNAs were reconstructed using the homolog rat cDNAs as baits for a Basic Local Alignment Search Tool search of Mouse expressed sequence tag. Comparisons of the putative cDNAs of the SCN1, SCN2, and SCN3 isoforms allowed the characterization of short regions of strict identity that were used to design primers for the ubiquitous PCRs SCNUA and SCNUB. To prevent any artifactual amplification of genomic DNA, we ensured that each of the cDNA regions targeted by our PCRs contained at least one intron. Except for calretinin, the corresponding genes were not present in public access libraries, and the analysis of the intron-exon organization was done by MegaBlast searching the National Center for Biotechnology Information Mouse Trace Archive database (http:// www.ncbi.nlm.nih.gov/Traces/trace.fcgi). In this way, we predicted five and three exons in the genomic sequences corresponding, respectively, to PCRs SCNUA and SCNUB. This prediction is in full agreement with the genomic organization of human genes SCN2A (GenBank accession numbers AF327225 to AF327229) and SCN3A (GenBank accession numbers AF330116 to AF330135). This was further confirmed by a control PCR on mouse genomic DNA: PCR SCNUA and the PCR for reelin did not yield a detectable product under our experimental conditions, whereas PCR SCNUB and PCRs for actine and calretinin gave products larger than the corresponding cDNAs. Comparisons of the putative cDNA of the SCN1, SCN2, and SCN3 isoforms allowed the characterization of short regions of strict identity that were used to design primers for the ubiquitous PCRs SCNUA and SCNUB. The regions encompassing PCRs SCNUA and SCNUB were checked for each isoform by direct RT-PCR and sequencing from adult or embryonic RNA. Restriction digest of PCR SCNUA by an enzyme such as Bsp143-I (Fermentas, an isoschizomer of Sau3A) gives clearly distinct patterns that allow the relative quantification of the expression of the three $\mathrm{SCN}$ isoforms. This method worked well when starting from tissue total RNA, but PCR
SCNUA proved poorly sensitive in single-cell experiments. Thus, for single-cell experiments, the relative expression of the three isoforms was analyzed by the direct sequencing of the PCR-SCNUB products.

\section{Results}

\section{E12-E13 VZ cells have only a delayed outward} potassium current

Mouse VZ cells are not extensively electrically coupled as they are in the rat (Picken-Bahrey and Moody, 2003a). The mean input resistance reported here $\left(R_{\text {in }}=3800 \pm 1028 \mathrm{M} \Omega\right)$ is close to a single uncoupled cell value estimated by Lo Turco and Kriegstein (1991) by extrapolation of their plot of dye-coupled cluster size versus $R_{\text {in }}$ to a cluster size of $1(2600 \mathrm{M} \Omega)$, and our measured cell capacitance $\left(C_{\mathrm{m}}\right)$ of $5.4 \pm 1.5 \mathrm{pF}$ is consistent with a single-cell electrical compartment with a diameter of $13 \mu$. This relative lack of electrical coupling allowed us to voltage clamp VZ cells without recourse to uncoupling methods (Mienville et al., 1994) and greatly improved the accuracy of our current measurements (Picken-Bahrey and Moody, 2003a,b). In our experiments, there were no significant differences between E12 and E13 VZ cells, so they have been analyzed together.

At E12-E13, all VZ cells $(n=30)$ had a delayed outward potassium current, activated by depolarization (Fig. $1 B$ ). This current was totally inhibited by replacing $\mathrm{K}$ with $\mathrm{Cs}$ in the pipette solution (data not shown; $n=10$ ). The mean $I_{\mathrm{K}}$ amplitude was $317 \pm 135 \mathrm{pA}$ at $+61 \mathrm{mV}(62.6 \pm 32.5 \mathrm{pA} / \mathrm{pF})$, a value the same as found in E14 VZ cells (Picken-Bahrey and Moody, 2003a). The current first activated at $-12.7 \pm 9 \mathrm{mV}$. No inward currents and no hyperpolarization-activated currents were seen in any VZ cell.

\section{An inward sodium current appears as postmitotic neurons invade the PP}

We studied 255 cells from the E12-E13 PP (Fig. 1C--E). There was no significant difference in the input resistance between E12E13 VZ and PP $(3800 \pm 1028 \mathrm{M} \Omega$ in VZ vs $5228 \pm 412 \mathrm{M} \Omega$ in $\mathrm{PP}$; $p=0.2)$ or in the cell capacitance $(5.4 \pm 1.5 \mathrm{pF}$ in $\mathrm{VZ}$ vs $6.2 \pm 2.4$ $\mathrm{pF}$ in PP; $p=0.12)$. The K current density, however, was significantly smaller in the PP cells $(45.3 \pm 30.6 \mathrm{pA} / \mathrm{pF}$ in $\mathrm{PP}$ vs $62.6 \pm$ $32.5 \mathrm{pA} / \mathrm{pF}$ in $\mathrm{VZ} ; p=0.008)$.

More than half of the PP cells (55\%; 141 of 255) expressed an inward $\mathrm{Na}$ current in addition to the potassium current (Fig. $1 D, E)$. This Na current is expressed at a mean density of $27.6 \pm$ $22.7 \mathrm{pA} / \mathrm{pF}$ (amplitude measured at the current peak) and is completely blocked by $10 \mathrm{nM}$ TTX (data not shown). The proportion of PP cells expressing $\mathrm{Na}^{+}$currents was the same at E12 and E13 [54\% at $\mathrm{E} 12(n=98)$ vs $56 \%$ at $\mathrm{E} 13(n=157)]$.

\section{There are two cell populations in the $\mathrm{PP}$, as determined by the ion channel populations}

The PP cells that express functional $\mathrm{Na}$ currents seem to represent a distinct subpopulation. Figure $2 A$ shows the distribution of $\mathrm{Na}$ current densities in our sample of PP cells. A second-order regression fit to $\mathrm{Na}$ currents greater than zero predicts (with a $99 \%$ confidence limit) that between 15 and 21 cells of this population should have no detectable Na current, whereas in our sample 115 such cells were found. This indicates that $\sim 85 \%$ of the cells without $\mathrm{Na}$ current belong to a separate population from those with detectable $\mathrm{Na}$ current. We observed no correlation between cell morphology from dye-fill experiments and the presence or absence of $\mathrm{Na}$ current.

Discriminating the two populations reveals other significant differences between PP cells that do or do not express Na currents (Fig. 2C). Cell capacitance is significantly higher in the Na plus $\mathrm{K}$ 
A

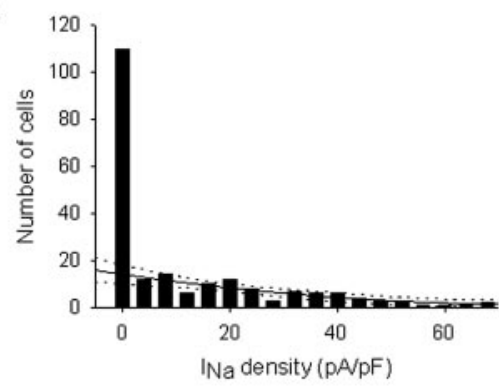

B

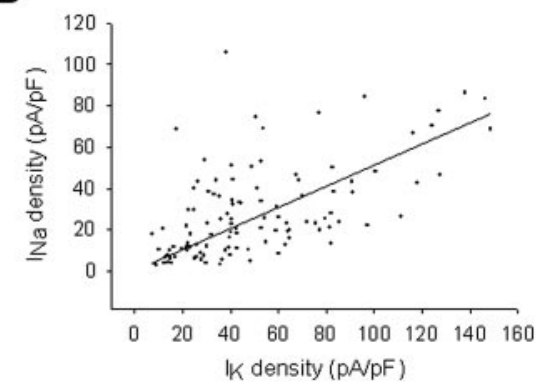

C
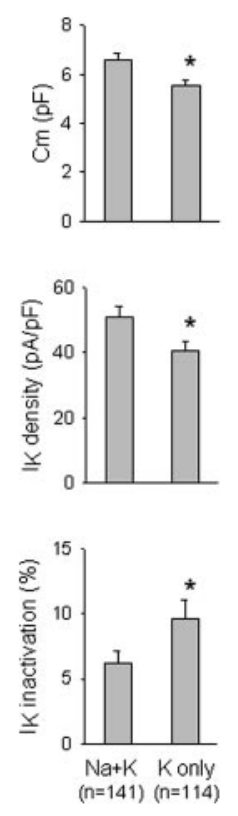

Figure 2. Two different cell populations in the PP defined by their ion channel properties. $A$, Frequency histogram of $\mathrm{Na}$ current densities (pA/pF) in PP cells $(n=255)$, divided in 18 bins, with the second-order regression curve fitting to the cells expressing a non-zero $\mathrm{Na}$ current (black solid line) and its $99 \%$ confidence intervals (dotted lines). This relationship predicts only $\sim 15 \%$ of the zero-Na current cells actually detected, indicating that most zero-Na current cells belong to a distinct population. Fitting a single Gaussian distribution to the non-zero Na current values predicts even fewer zero-Na current cells, and thus a greater percentage of zero-Na current cells, that belong to a separate population. B, Positive correlation between $\mathrm{Na}$ current density and $K$ current density among PP cells $(r=0.631)$. A first-order regression fit is shown. C, Cell capacitance $\left(C_{m}\right.$; top), K current density (middle), and K current inactivation (bottom) are significantly different between PP cells with and without detectable Na currents. Data are presented as mean \pm SEM; asterisks denote a significant difference $(p<0.05)$.

population $[6.6 \pm 2.7 \mathrm{pF}$ in the Na plus $\mathrm{K}(n=141)$ vs $5.6 \pm 1.7$ $\mathrm{pF}$ in the $\mathrm{K}$ only $(n=114) ; p=0.003)$, as is the K current density $(55.2 \pm 54.3 \mathrm{pA} / \mathrm{pF}$ in the Na plus K vs $40.7 \pm 24.6 \mathrm{pA} / \mathrm{pF}$ in the $\mathrm{K}$ only; $p=0.03)$. The $\mathrm{K}$ current inactivation is statistically significantly smaller in the $\mathrm{Na}$ plus K population $(5.9 \%$ in the $\mathrm{Na}$ plus $\mathrm{K}$ vs $11.1 \%$ in the $\mathrm{K}$ only, measured at $80 \mathrm{msec} ; p=0.004$ ). Moreover, there is a positive correlation between the Na current density and the K current density (Fig. $2 B$ ), suggesting that these two currents are under coordinated developmental control in these cells. The fact that cell capacitance is higher in the Na plus $\mathrm{K}$ population may be correlated to the process development of some PP cells.

To ensure that the presence of the K current was not affecting our measurement of the Na current, we inhibited $I_{\mathrm{K}}$ by replacing intracellular $\mathrm{K}$ with $\mathrm{Cs}(n=63)$ and found the same proportion of Na plus $\mathrm{K}$ and $\mathrm{K}$ only cells ( $49 \%$ of $I_{\mathrm{Na}}$ in Cs vs $55 \%$ in $\mathrm{K} ; p=$ 0.48; two-tailed Fisher's exact test). This indicates that the presence of delayed $\mathrm{K}$ currents does not interfere with our ability to detect $\mathrm{Na}$ currents. [The Na current amplitude and density were actually somewhat smaller with Cs in the pipette $(18.4 \pm 16.1$ $\mathrm{pA} / \mathrm{pF}$ in $\mathrm{Cs}$ vs $27.6 \pm 22.6 \mathrm{pA} / \mathrm{pF}$ in $\mathrm{K} ; p=0.02)$. We have made a similar observation for $\mathrm{Na}^{+}$currents in the E14 VZ (PickenBahrey and Moody, 2003a). This could be attributable to an effect of the Cs on the Na channel itself or on the surface charges of the cell membrane that can affect the $\mathrm{Na}$ channel conductance via both gating and permeation mechanisms (Ohmori and Yoshii, 1977).]
A

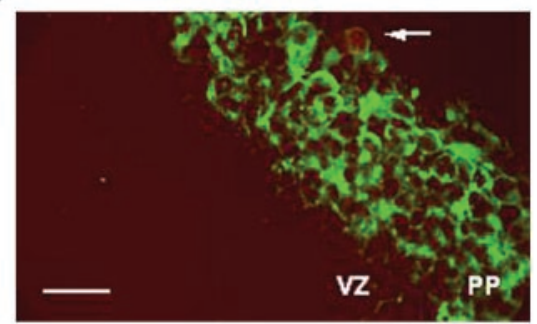

B

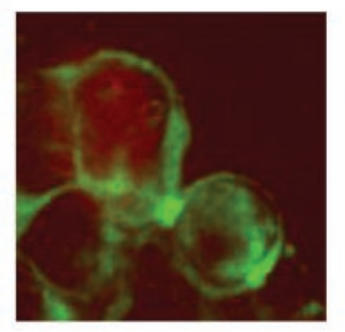

C

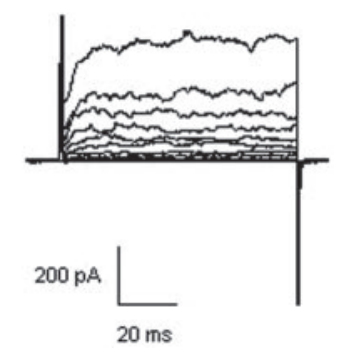

Figure 3. The two PP cell populations are neuronal cells. A, Merged images showing a representative TuJ1 staining (green cells) of an E13 slice and the recorded cell filled with Texas Red Dextran 3000 MW (red cell close to the arrow) applied through the patch pipette $(n=10)$. Scale bar, $25 \mu \mathrm{m}$. B, A higher magnification shows that the recorded cell is surrounded by TuJ1 staining. $C$, Corresponding potassium outward current recorded under depolarization of the red stained cell shown in $A$ and $B$.

\section{Correlation between the sodium current appearance and cellular phenotypes in the PP zone}

To see whether Na current expression marks an identifiable neuronal population in the $\mathrm{PP}$, we marked a series of recorded cells by filling them with Texas Red Dextran 3000 MW and then counterstaining with antibodies directed against either neural-specific tubulin (TuJ1) or calretinin. The monoclonal antibody TuJ1 specifically recognizes neuron-specific class III $\beta$ tubulin and has been used to identify differentiating and postmitotic neurons during neurogenesis (Menezes and Luskin, 1994). Calretinin is a neuron-specific calcium-binding protein found in at least one subpopulation of Cajal-Retzius cells during mouse neurogenesis (Soriano et al., 1994; Del Rio et al., 1995; Fonseca et al., 1995). Recent reports indicate that calretinin may also be found in other pioneer neuron populations in the embryonic rat cortex (Meyer et al., 1998). The antibody anti-calretinin used here reacts with both calcium-bound and unbound conformations of calretinin.

We first confirmed that all PP cells are TuJ1 positive by double-staining a series of slices with DAPI and TuJ1 (data not shown). We next showed for a sample of 10 recorded and filled cells that TuJ1 immunoreactivity was present whether or not the cells expressed a detectable $\mathrm{Na}$ current (an example showing a $\mathrm{TuJ1}$-positive cell with no Na current is presented Fig. 3).

We next tested whether the Cajal-Retzius cells, the first neurons to enter the PP (Frotscher, 1998; Marin-Padilla, 1998), were the population that expressed $\mathrm{Na}$ currents. Double labeling showed that $\sim 12 \%$ of the TuJ1-positive cells are calretinin positive in the E12 or E13 PP ( $n=450$ cells from 16 slices; data not shown). We were able to recover 16 cells after patch clamping and dye filling and successfully stain them for calretinin immunoreactivity (two examples are shown in Fig. 4). (It proved difficult to remove the whole-cell pipette after recording without also removing the recorded cell from the slice.) All five cells that were calretinin positive also expressed detectable $I_{\mathrm{Na}}$. All six cells that 


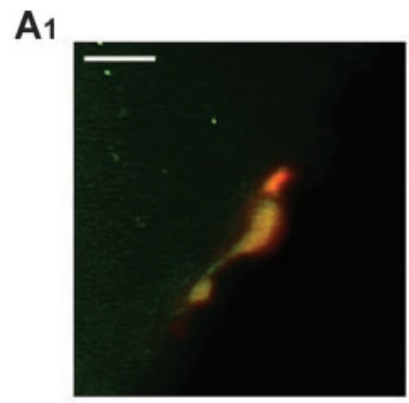

Calretinin positive

B1

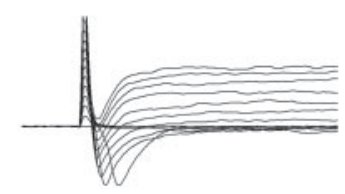

A2

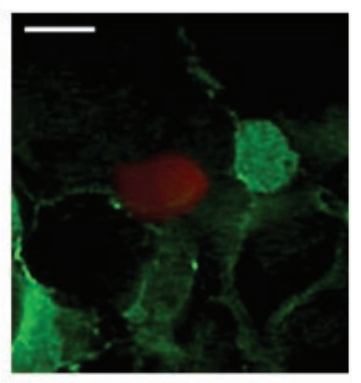

Calretinin negative

B2

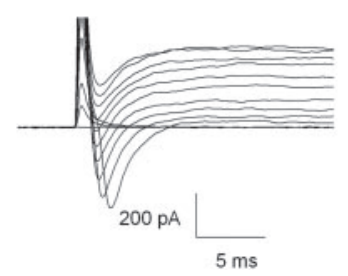

Figure 4. Calretinin-positive cells always express a Na current. A1, $A 2$, Merged images showing representative calretinin staining (green cells) of E12 and E13 slices and the recorded cells filled with Texas Red Dextran 3000 MW (red cells) $(n=16)$. Scale bars, $10 \mu \mathrm{m}$. B1, B2, Corresponding currents recorded under depolarization of the red stained cells shown in the top panels. Only the first 30 msec of the recording are shown.

had no detectable $I_{\mathrm{Na}}$ were calretinin negative. However, five additional cells were calretinin negative and did express $I_{\mathrm{Na}}$. Thus, the Cajal-Retzius phenotype, as judged by calretinin expression, is specifically associated with $I_{\mathrm{Na}}$ expression, but the calretininnegative phenotype is variable with regard to $I_{\mathrm{Na}}$ expression.

None of the cells we tested that expressed $I_{\mathrm{Na}}$ was capable of generating overshooting action potentials in response to depolarizing stimuli under current clamp nor did any fire repetitively. The amplitude of $I_{\mathrm{Na}}$ at this early stage is probably too small, or its time course too fast in relation to the long membrane time constant, to support full action potentials.

\section{Correlation between the sodium channel appearance and molecular phenotypes in the PP zone}

To better correlate the appearance of the Na current to the CajalRetzius cell population and to ask whether early in their differentiation some Cajal-Retzius cells might be expressing Na channel transcripts but not yet have functional channel proteins, we performed single-cell RT-PCR experiments coupled with patchclamp experiments. We were able to record from 56 cells and apply RT-PCR, of which 49 (87\%) were successful as judged by amplification of our control marker, $\beta$-actin. The present multiplex RT-PCR procedure allows the simultaneous characterization of the expression of several markers on a single cell. We chose reelin and calretinin as specific cellular markers for Cajal-Retzius cells. Because RT-PCR allows detection of channel expression at a transcriptional level, to correlate with functional channel protein expression measured by patch-clamp recordings, we also amplified transcripts of brain Na channel $\alpha$-subunit isoforms.

Four $\alpha$-subunits are known to be associated with TTXsensitive $\mathrm{Na}$ currents in the brain: $\mathrm{Na}_{\mathrm{v}} 1.1, \mathrm{Na}_{\mathrm{v}} 1.2, \mathrm{Na}_{\mathrm{v}} 1.3$, and $\mathrm{Na}_{\mathrm{v}} 1.6$ (expressed by genes $S C N 1, S C N 2, S C N 3$, and $S C N 8$, respectively). Among these, $\mathrm{Na}_{\mathrm{v}} 1.6$ (SCN8) is known to be expressed as a truncated form, incompatible with a $\mathrm{Na}$ current,

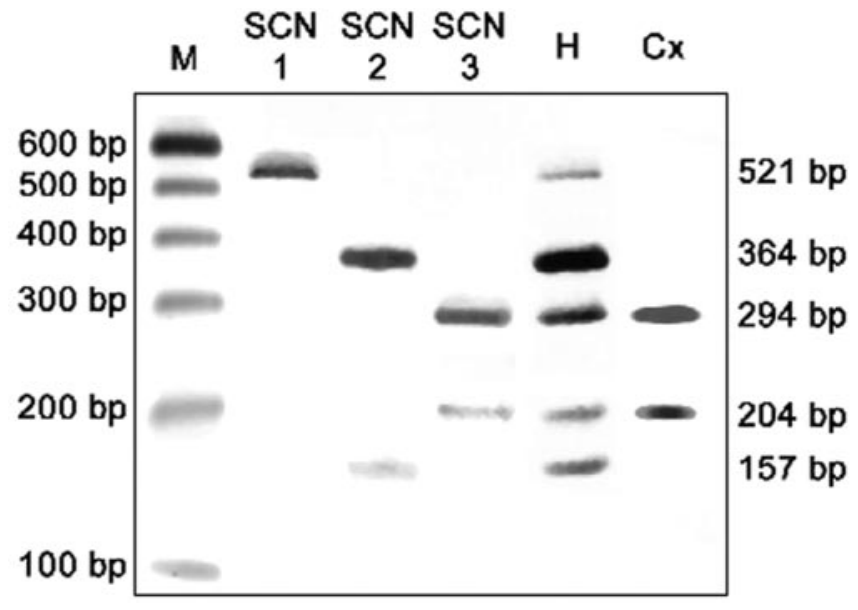

Figure 5. Relative quantification of SCN isoforms by competitive RT-PCR. RT-PCRSCNUA (see Table 1 for primers) allows the competitive coamplification of CDNA fragments from SCN1, SCN2, and SCN3 mRNAs. The corresponding PCR products are 556 bp long for SCN 1 and SCN2 and 560 bp long for SCN3. Restriction digestion of the pure SCN1 isoform PCR product by Bsp143-I results in two fragments of 521 and 35 bp (lane SCN1), whereas the same digestion results in three fragments for pure $\mathrm{SCN} 2(364,157$, and $35 \mathrm{bp})$ and four fragments for pure SCN3 isoform (294, 204,35, and 27 bp) (lanes SCN2 and SCN3, respectively). The presence and relative intensity of these different fragments can, thus, give an estimation of the relative contribution of the three different isoforms in total RNA from E13 brain hemispheres $(\mathrm{H})$ or from microdissected E13 neocortex (CX). M, 100 bp molecular weight markers.

from E12.5 to E14.5 in embryonic mouse (Plummer et al., 1997) (confirmed in our hands). We, therefore, focused our study on the expression of SCN isoforms 1, 2, and 3. We designed two different RT-PCRs, PCR-SCNUA and PCR-SCNUB, with primers localized in sequences regions fully conserved between the three SCN isoforms. The PCR-SCNUA target sequence is located in the $5^{\prime}$ part of the coding sequence of SCNs, whereas PCRSCNUB mapped is in the $3^{\prime}$ part of the coding sequence of these RNAs (locations deduced from the comparison with rat SCN isoforms).

To determine which $\mathrm{Na}$ channel isoform was likely to dominate expression in the PP, we isolated total RNA from microdissected neocortices of E13 mice. RT-PCR SCNUA conducted on this material demonstrated the exclusive expression of isoform SCN3 (Fig. 5). This observation was independently confirmed by single-cell RT-PCR using the second PCR, SCNUB. The sequence electrophoretograms of six SCNUB products originating from six independent cells presented a clear and unique sequence corresponding to isoform SCN3 ( $n=6$ of 6 ; data not shown). To control for adequate detection of SCN1 and 2 isoforms, we repeated this analysis using whole cerebral hemispheres rather than microdissected neocortices. In whole hemispheres, PCR SCNUA showed expression of all three isoforms, with SCN1 being at the lowest level (Fig. 5).

Coanalysis at the transcripts level of calretinin and reelin expression in PP cells showed that calretinin-positive cells were always reelin positive but that only $44 \%$ of reelin-positive cells were also calretinin positive. This indicates that reelin is a more accurate marker for Cajal-Retzius cells and that, in agreement with the results of Meyer et al. (1998) and Lavdas et al. (1999), calretinin expression identifies only a subset of these cells.

We further analyzed the correlation between reelin expression, SCN transcript expression, and the presence of functional $\mathrm{Na}$ and K currents (Fig. 6). Virtually all Cajal-Retzius cells, judged by reelin expression, expressed $\mathrm{Na}$ channel transcript (97\%; 31 of 32 cells) (Fig. 6A,B). There remained, however, a significant 
A
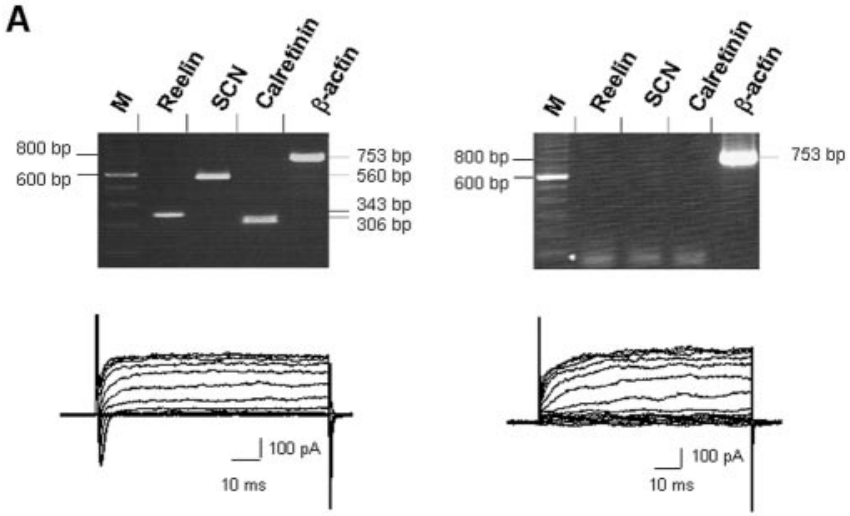

B
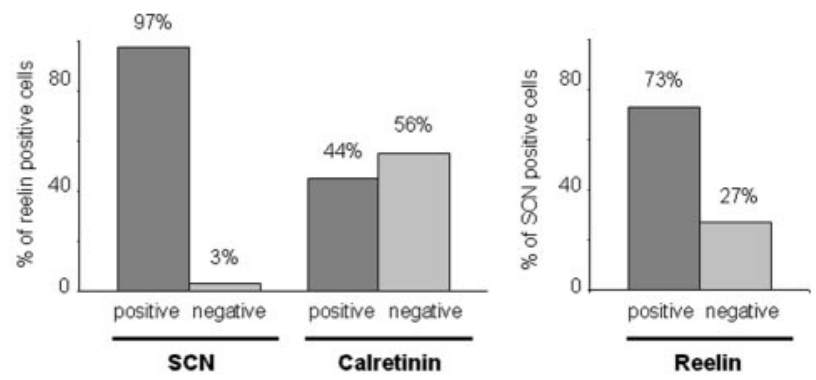

Figure 6. Single-cell RT-PCR evidence for a differential expression of reelin, calretinin, and Na channel $\alpha$-subunit (SCN1a, 2a, and 3a) in the PP cells. A, Agarose gel analysis of two representative cells. The left panel corresponds to a typical Cajal-Retzius cell that proves positive to reelin, SCN, and calretinin and possessed also a Na current. On the contrary, the right panel corresponds to a typical non-Cajal-Retzius cell that was negative for the Na current. In this last case, the $\beta$-actin-positive control is essential to ascertain that this observation does not stem from a false negative RT-PCR ( $M$, molecular weight marker). $B$, Histograms summarizing singlecell RT-PCR experiments ( $n=49$ ) and comparing $S C N$ versus reelin expression (left), calretinin versus reelin expression (middle), and reelin versus SCN expression (right).

number of cells that expressed $\mathrm{Na}$ channel transcripts that were reelin negative (27\% of all SCN-positive cells) (Fig. 6B). Although virtually all reelin-positive (Cajal-Retzius) cells expressed SCN transcripts, only $41 \%$ expressed detectable Na currents. This implies that reelin and $\mathrm{Na}$ channel transcription are early and correlated events in the differentiation of Cajal-Retzius cells and that the appearance of functional $\mathrm{Na}$ channel proteins in the membrane occurs somewhat later. (This percentage is unlikely to be an artifact of PCR amplification or patch-clamp recording, because we were able to confirm that $100 \%$ of PP cells that expressed detectable $\mathrm{Na}$ currents were positive for SCN transcripts.)

Overall, the results of our single-cell RT-PCR experiments confirm the results of our immunostaining experiments: all Cajal-Retzius cells express $\mathrm{Na}$ channel genes of the SCN3 isoform, and even as early as E12-E13, a large fraction of these have functional $\mathrm{Na}$ channel proteins in the plasma membrane. $\mathrm{Na}$ channel expression is not, however, exclusively a property of Cajal-Retzius cells at this stage. There is another, as yet unidentified, population of PP cells that also expressed $\mathrm{Na}$ channel transcripts and $\mathrm{Na}$ currents.

\section{Discussion}

In the experiments reported here, we have combined patchclamp recording, immunocytochemisty, and single-cell RT-PCR methods to study the early differentiation of PP cells in the embryonic mouse neocortex. In the proliferative VZ from which the
PP cells arise, cells express only delayed outward K currents. This has been shown for VZ cells at E9 (M. Albrieux and W. J. Moody, unpublished observations) and here for E12-E13. The first stage at which we detect $\mathrm{Na}$ currents in neocortical VZ cells is E14 (Picken-Bahrey and Moody, 2003a).

As the earliest neurons of the cortex enter the PP, some begin to express inward Na currents in addition to the outward $\mathrm{K}$ currents. To investigate which subpopulations of PP cells expressed $\mathrm{Na}$ currents at these early stages, and how that functional expression of $\mathrm{Na}$ channel proteins was related to transcription of specific Na channel genes, we performed RT-PCR to detect specific cell type markers and $\mathrm{Na}$ channel transcripts on PP cells that had been subjected to whole-cell patch-clamp recording. The results showed that of the Cajal-Retzius cell population, identified by amplification of transcripts for the secreted protein reelin, 97\% also expressed Na channel transcripts. RT-PCR on microdissected neocortices at this stage and direct sequencing of singlecell PCR products indicated that these transcripts were of the SCN3 Na channel subtype, in keeping with the results obtained in E12 rat brain using Northern blot (Beckh et al., 1989). Among these Cajal-Retzius cells expressing $\mathrm{Na}$ channel transcripts, only about half $(41 \%)$ showed detectable $\mathrm{Na}$ currents in whole-cell recordings. This indicates, as expected, a time lag between $\mathrm{Na}$ channel transcription and the insertion of functional $\mathrm{Na}$ channels into the plasma membrane. Thus, $\mathrm{Na}$ channel expression and the appearance of inward $\mathrm{Na}$ currents are very early events in the differentiation of Cajal-Retzius cells.

The early expression of the SCN3 Na channel subtypes in PP cells is correlated temporally with the appearance of the ryanodine receptor form of intracellular Ca release channel. At E13, VZ cells express only the $\mathrm{InsP}_{3}$ type of Ca release channel. At the same stage in the PP, $60 \%$ of the cells also express the RyR release channel (Faure et al., 2001). The simultaneous appearance of these two important channels at this stage suggests that their combined action, possibly in activity-dependent triggering of intracellular Ca release, may play an important developmental role in these pioneer neuron populations of the PP.

In embryonic rat cortex, Mienville and Barker (1997) and Mienville and Pesold (1999) reported that Cajal-Retzius cells lacked a functional Na current at E18, although one is present in this population a few days later, at early postnatal stages (Zhou and Hablitz, 1996). In all these studies, Cajal-Retzius cells were identified by morphological criteria only, which our results indicate do not correspond to identification based on specific molecular markers. In contrast, because marked differences have been described in other physiological properties of cells of embryonic rat and mouse cortex (Picken-Bahrey and Moody, 2003a), it is possible that the properties of the Cajal-Retzius cells differ in rat and mouse.

The use of calretinin and reelin as markers for embryonic Cajal-Retzius cells requires some comment. Recent experiments in embryonic rat cortex have shown that as early as E11.5 there is a population of calretinin-positive pioneer neurons in layer I that are reelin negative (by antibody staining) and do not appear by morphological criteria to be Cajal-Retzius cells (Meyer et al., 1998). These authors argue further that, at these early stages, reelin-positive neurons are not true Cajal-Retzius cells but rather a precursor population (termed subpial granule neurons) that is the precursor to postnatal Cajal-Retzius cells and one other cell type (subpial pyriform cells). We have defined the Cajal-Retzius cell population in our experiments as reelin-positive cells. The fact that this population may be a precursor to Cajal-Retzius cells does not materially change our conclusions, namely that expres- 
sion of the SCN3 sodium channel gene and the functional current are very early events in the differentiation of Cajal-Retzius neurons, but events that are not exclusive to that population. Other criteria for identifying Cajal-Retzius neurons postnatally cannot easily be applied in our experiments are early embryonic stages. For example, the electrophysiological characteristics of postnatal Cajal-Retzius neurons, the presence of $I_{\mathrm{H}}$, for example (Kilb and Luhmann, 2000), have not yet developed at E12-E13 (M. Albrieux and W. J. Moody, unpublished observations). Similarly, the bipolar morphology and characteristic subpial distance of postnatal Cajal-Retzius neurons are not specifically indicative at early stages (Albrieux and Moody, unpublished observations from biocytin fills) (Meyer et al., 1998).

In our experiments, all calretinin-positive cells were also reelin positive, indicating either that our recordings never targeted the early pioneer neurons reported by these authors (which are calretinin positive but reelin negative), or that the combination of calretinin and reelin immunoreactivity does not identify these cell types in mouse as it does in rat, or that these cells are expressing reelin RNA (dectected in our PCR protocol) but not reelin protein [as would be detected by the antibody protocol of Meyer et al. (1998) [. So, it remains unclear whether we can attribute part of our population of reelin-negative neurons that have functional sodium currents to these pioneer cells. An intriguing possibility is that this second population represents future SP cells. In either case, early $\mathrm{Na}$ current expression would be a characteristic of pioneer neurons generally rather than just Cajal-Retzius cells, suggesting that Na currents might play an early role either in the pioneer function of these cells or in their later death.

\section{References}

Beckh S, Noda M, Lubbert H, Numa S (1989) Differential regulation of three sodium channel messenger RNAs in the rat central nervous system during development. EMBO J 8:3611-3616.

Chun JJ, Shatz CJ (1989a) The earliest-generated neurons of the cat cerebral cortex: characterization by MAP2 and neurotransmitter immunohistochemistry during fetal life. J Neurosci 9:1648-1667.

Chun JJ, Shatz CJ (1989b) Interstitial cells of the adult neocortical white matter are the remnant of the early generated subplate neuron population. J Comp Neurol 282:555-569.

Chun JJ, Nakamura MJ, Shatz CJ (1987) Transient cells of the developing mammalian telencephalon are peptide-immunoreactive neurons. Nature 325:617-620.

De Carlos JA, Lopez-Mascaraque L, Valverde F (1996) Dynamics of cell migration from the lateral ganglionic eminence in the rat. J Neurosci 16:6146-6156.

Del Rio JA, Martinez A, Fonseca M, Auladell C, Soriano E (1995) Glutamate-like immunoreactivity and fate of Cajal-Retzius cells in the murine cortex as identified with calretinin antibody. Cereb Cortex $5: 13-21$.

Faure AV, Grunwald D, Moutin MJ, Hilly M, Mauger JP, Marty I, De Waard M, Villaz M, Albrieux M (2001) Developmental expression of the calcium release channels during early neurogenesis of the mouse cerebral cortex. Eur J Neurosci 14:1613-1622.

Fonseca M, Del Rio JA, Martinez A, Gomez S, Soriano E (1995) Development of calretinin immunoreactivity in the neocortex of the rat. J Comp Neurol 361:177-192.

Frotscher M (1998) Cajal-Retzius cells, Reelin, and the formation of layers. Curr Opin Neurobiol 8:570-575.

Frotscher M, Seress L, Abraham H, Heimrich B (2001) Early generated Cajal-Retzius cells have different functions in cortical development. Symp Soc Exp Biol 53:43-49.

Kim GJ, Shatz CJ, McConnell SK (1991) Morphology of pioneer and follower growth cones in the developing cerebral cortex. J Neurobiol 22:629-642.

Kilb W, Luhmann HJ (2000) Characterization of a hyperpolarizationactivated inward current in Cajal-Retzius cells in rat neonatal cortex. J. Neurophysiol 84:1681-1691.
Lambolez B, Audinat E, Bochet P, Crepel F, Rossier J (1992) AMPA receptor subunits expressed by single Purkinje cells. Neuron 9:247-258 .

Lavdas AA, Grigoriou M, Pachnis V, Parnavelas JG (1999) The medial ganglionic eminence gives rise to a population of early neurons in the developing cerebral cortex. J Neurosci 19:7881-7888.

Lo Turco JJ, Kriegstein AR (1991) Clusters of coupled neuroblasts in embryonic neocortex. Science 252:563-566.

Luskin MB, Shatz CJ (1985) Studies of the earliest generated cells of the cat's visual cortex: cogeneration of subplate and marginal zones. J Neurosci 5:1062-1075.

Marin-Padilla M (1998) Cajal-Retzius cells and the development of the neocortex. Trends Neurosci 21:64-71.

McConnell SK (1995) Constructing the cerebral cortex: neurogenesis and fate determination. Neuron 15:761-768.

McConnell SK, Ghosh A, Shatz CJ (1994) Subplate pioneers and the formation of descending connections from cerebral cortex. J Neurosci 14:1892-1907.

Menezes JR, Luskin MB (1994) Expression of neuron-specific tubulin defines a novel population in the proliferative layers of the developing telencephalon. J Neurosci 14:5399-5416.

Meyer G, Soria JM, Martinez-Galan JR, Martin-Clemente B, Fairen A (1998) Different origins and developmental histories of transient neurons in the marginal zone of the fetal and neonatal rat. J Comp Neurol 397:493-518.

Mienville JM, Barker JL (1997) Potassium current expression during prenatal corticogenesis in the rat. Neuroscience 81:163-172.

Mienville JM, Pesold C (1999) Low resting potential and postnatal upregulation of NMDA receptors may cause Cajal-Retzius cell death. J Neurosci 19:1636-1646.

Mienville JM, Lange GD, Barker JL (1994) Reciprocal expression of cell-cell coupling and voltage-dependent $\mathrm{Na}$ current during embryogenesis of rat telencephalon. Brain Res 77:89-95.

Moody WJ, Bosma MM (1985) Hormone-induced loss of surface membrane during maturation of starfish oocytes: differential effects on potassium and calcium channels. Dev Biol 112:396-404.

Ohmori H, Yoshii M (1977) Surface potential reflected in both gating and permeation mechanisms of sodium and calcium channels of the tunicate egg cell membrane. J Physiol (Lond) 267:429-463.

Picken-Bahrey HL, Moody WJ (2003a) Voltage-gated currents, dye and electrical coupling in the embryonic mouse neocortex. Cereb Cortex 13:239-251.

Picken-Bahrey HL, Moody WJ (2003b) . Early development of voltagegated ion currents and firing properties in neurons of the mouse cerebral cortex. J Neurophysiol 89:1761-1773.

Plummer NW, McBurney MW, Meisler MH (1997) Alternative splicing of the sodium channel SCN8A predicts a truncated two-domain protein in fetal brain and non-neuronal cells. J Biol Chem 272:24008-24015.

Radnikow G, Feldmeyer D, Lubke J (2002) Axonal projections, input and output synapses, and synaptic physiology of Cajal-Retzius cells in the developing rat neocortex. J Neurosci 22:6908-6819.

Shatz CJ, Luskin MB (1986) The relationship between the geniculocortical afferents and their cortical target cells during development of the cat's primary visual cortex. J Neurosci 6:3655-3668.

Soriano E, Del Rio JA, Martínez A, Super H (1994) Organization of the embryonic and early postnatal murine hippocampus. I. Immunocytochemical characterization of neuronal populations in the subplate and marginal zone. J Comp Neurol 342:571-595.

Soriano E, Alvarado-Mallart RM, Dumesnil N, Del Ri-JA, Sotelo C (1997) Cajal-Retzius cells regulate the radial glia phenotype in the adult and developing cerebellum and alter granule cell migration. Neuron 18:563-577.

Takahashi T, Nowakowski RS, Caviness Jr VS (1995) The cell cycle of the pseudostratified ventricular epithelium of the embryonic murine cerebral wall. J Neurosci 15:6046-6057.

Takahashi T, Nowakowski RS, Caviness Jr VS (1996) The leaving or Q fraction of the murine cerebral proliferative epithelium: a general model of neocortical neuronogenesis. J Neurosci 16:6183-6196.

Valverde F, De Carlos JA, Lopez-Mascaraque L (1995) Time of origin and early fate of preplate cells in the cerebral cortex of the rat. Cereb Cortex 5:483-493.

Zhou FM, Hablitz JJ (1996) Postnatal development of membrane properties of layer I neurons in rat neocortex. J Neurosci 16:1131-1139. 